\title{
Temporal dynamics of natural communities of marine algal viruses and eukaryotes
}

\author{
Steven M. Short ${ }^{1,3}$, Curtis A. Suttle ${ }^{2, *}$ \\ ${ }^{1}$ Department of Botany, University of British Columbia, 6270 University Boulevard, Vancouver, \\ British Columbia V6T 1Z4, Canada \\ ${ }^{2}$ Departments of Earth and Ocean Sciences, Microbiology and Immunology, and Botany, University of British Columbia, \\ 6270 University Boulevard, Vancouver, British Columbia V6T 1Z4, Canada \\ ${ }^{3}$ Present address: Ocean Sciences Department, University of California, Santa Cruz, California 95064, USA
}

\begin{abstract}
The composition of algal virus communities in relation to temperature, salinity, chlorophyll a ( $\mathrm{chl}$ a) concentration and eukaryotic community composition was monitored at a single location for $14 \mathrm{mo}$. Changes in algal virus and eukaryote communities were determined using polymerase chain reaction (PCR) and denaturing gradient gel electrophoresis (DGGE) to generate genetic fingerprints. Sequence analysis of bands extracted from denaturing gradient gels revealed the presence of at least 5 distinct viruses as well as temporally dynamic and diverse communities of eukaryotes that included taxa from the viridiplantae, fungi and metazoa. Comparison of algal virus fingerprints with environmental conditions revealed that, at certain times, changes in algal virus community composition were coincident with changes in tide height, salinity or chl a concentration. However, algal virus community changes were not often coupled to eukaryote community changes. The lack of coincidence between changes in virus and eukaryote communities can be explained by the presence of organisms that were not hosts of the detected viruses. It is likely that the uncoupling of $18 \mathrm{~S}$ and AVS fingerprints was due to succession among non-host eukaryotes. Although algal virus fingerprint patterns were stable throughout most of the study, stable eukaryote fingerprint patterns were observed only during the winter months. Furthermore, specific taxa of algal viruses persisted in fluctuating physical and biological environments. We concluded that the constant production of, and mortality from, some taxa of algal viruses provide further evidence that algal viruses affect phytoplankton community structure and dynamics.
\end{abstract}

KEY WORDS: Algal viruses · Phycodnaviridae $\cdot$ Eukaryotes $\cdot$ DGGE $\cdot$ Molecular fingerprints $\cdot$ Diversity Resale or republication not permitted without written consent of the publisher

\section{INTRODUCTION}

After the discovery that viruses were abundant in the ocean, marine microbiologists quickly recognized their ecological importance (Thingstad et al. 1993, Bratbak et al. 1994, Suttle 1994). There is also mounting evidence that viruses have a significant effect on oceanic energy and material flow (Fuhrman 1999, Wilhelm \& Suttle 1999). Moreover, there is now compelling data showing that viruses are central players affecting phytoplankton communities in the sea (Suttle 2000). An important contribution to the study of viruses that infect marine phytoplankton was the development of polymerase chain reaction $(\mathrm{PCR})$ techniques that are specific for algal viruses belonging to the Phycodnaviridae (Chen \& Suttle 1995). Using these culture-independent PCR methods, sequences belonging to unknown taxa of algal viruses were amplified from the Gulf of Mexico demonstrating the utility of this molecular approach (Chen \& Suttle 1996). Subsequently, we developed a denaturing gradient gel electrophoresis (DGGE) protocol to resolve sequences amplified with the algal-virusspecific (AVS) PCR primers (Short \& Suttle 2000). Recently, molecular fingerprinting of algal virus communities facilitated the recovery of algal virus gene sequences from different environments revealing that groups of closely related algal viruses were geographically widespread (Short \& Suttle 2002). The results of that study demonstrated that although further refinement of the PCR and DGGE methods was necessary, these methods could be applied to the study of spatial changes in algal virus community composition. 
The diversity of complex microbial populations was first studied using DGGE when Muyzer and coworkers obtained molecular fingerprints of $16 \mathrm{~S}$ rDNA fragments amplified from an aerobically grown bacterial biofilm (Muyzer et al. 1993). Since then, DGGE has become a common method to obtain molecular fingerprints and has been used to study microbial diversity in many different contexts. For the most part, DGGE has been applied to the study of bacterial community composition as determined by PCR amplification of $16 \mathrm{~S}$ rDNA. DGGE has been used to examine the microbial community diversity of biostimulated shorelines (Ogino et al. 2001), hot spring microbial mats (Ferris et al. 1997), California estuaries (Murray et al. 1996) and the Arctic Ocean (Ferrari \& Hollibaugh 1999). In addition, DGGE has been applied to examine diversity in marine cyanophage (Wilson et al. 2000) and algal virus communities (Short \& Suttle 1999, 2002). Recently, PCR and DGGE fingerprinting methods have also been developed to examine the diversity of eukaryotic microbes (Van Hannen et al. 1998, Diez et al. 2001). These eukaryote fingerprinting techniques have been applied to investigations of the temporal variability of marine eukaryotes in an enclosure (Castberg et al. 2001) and the spatial variability through a salinity gradient in a solar saltern (Casamayor et al. 2002). However, to our knowledge, molecular fingerprinting has not been used to examine temporal changes in marine eukaryotic communities.

The primary goal of this study was to determine the annual variability in the genetic fingerprints of natural algal virus communities over a 64 wk period. Indirect evidence of changes in algal virus community composition has been noted when blooms of the alga Emiliania huxleyi have been succeeded by an increase in large virus-like particles or E. huxleyi viruses (Bratbak et al. 1993, Castberg et al. 2001). Furthermore, changes in aquatic viral assemblages have been examined by comparing genome size classes with pulsed field gel electrophoresis (Wommack et al. 1999, Steward et al. 2000). However, to date, no direct examination of temporal changes in algal virus community composition has been conducted. A secondary goal of this study was to relate changes in algal virus diversity, as inferred from molecular fingerprints, to changes in eukaryote diversity and the physical environment. The results of this study show that although the temporal changes of algal viruses and eukaryotes were not closely coupled, changes were evident in both communities. More importantly, this study demonstrates that changes in the composition of marine algal virus communities often coincide with changes in the environment.

\section{MATERIALS AND METHODS}

Sample collection. Using a bucket and funnel, $40 \mathrm{l}$ samples were collected weekly from the surface water at Jericho Pier, Vancouver, Canada (49 $\left.11^{\prime} \mathrm{N}, 123^{\circ} 10^{\prime} \mathrm{W}\right)$. Sample temperature and salinity were measured approximately $15 \mathrm{~min}$ after collection, and duplicate acetone extracted chlorophyll a (chl a) samples were measured fluorometrically using established protocols (Parsons et al. 1984). The virus-size fraction was concentrated using previously described methods (Suttle et al. 1991, Short \& Suttle 2002). Briefly, samples were pressure-filtered $(<17 \mathrm{kPa})$ through $142 \mathrm{~mm}$ in diameter glass fiber (GC50; nominal pore size $1.2 \mu \mathrm{m}$, Advantec MFS) and PVDF filters (GVWP; $0.45 \mu \mathrm{m}$ pore size, Millipore) connected in series. Remaining particulate material in the filtrates was concentrated to a final volume of ca. $200 \mathrm{ml}$ using a $30 \mathrm{kD}$ cutoff, Amicon S1Y30 (Millipore) cartridge. Concentrated samples were stored at $4^{\circ} \mathrm{C}$ in the dark. The glass fiber and PVDF filters were stored at $-20^{\circ} \mathrm{C}$ in the dark until nucleic acid extraction.

DNA extraction and PCR. Nucleic acids were extracted from virus-size-fraction concentrates, glassfiber filters and PVDF filters. Thirty-five ml subsamples of the virus-size concentrates were centrifuged in an RC80 ultracentrifuge with an AH629 rotor (Sorvall ${ }^{\circledR}$ ) at $28500 \mathrm{rpm}$ for $3.5 \mathrm{~h}$ at $20^{\circ} \mathrm{C}$. Nucleic acids were extracted from the resuspended pellets (100 $\mu \mathrm{l})$ using an established hot/cold technique (Chen et al. 1996). DNA was also extracted from aseptically excised $2 \mathrm{~cm}^{2}$ portions of the $142 \mathrm{~mm}$ in diameter filters. After Díez et al. (2001), filter subsamples were incubated at $37^{\circ} \mathrm{C}$ for 45 min in $500 \mu$ lysozyme (final concentration: $1 \mathrm{mg} \mathrm{ml}^{-1}$ ) and at $65^{\circ} \mathrm{C}$ for $1 \mathrm{~h}$ after a $500 \mu \mathrm{l}$ solution of sodium dodecyl sulfate (final concentration: $1 \%$ ) and Proteinase K (final concentration: $0.2 \mathrm{mg} \mathrm{ml}^{-1}$ ) was added. DNA was purified from the filter lysates by sequential extractions with equal volumes of phenol, phenol-chloroformisoamyl alcohol (25:24:1) and chloroform-isoamyl alcohol (24:1). Purified DNA was precipitated and washed with ethanol as described (Sambrook et al. 1989). Extracted DNA was stored at $-20^{\circ} \mathrm{C}$ in $10 \mathrm{mM}$ Tris- $\mathrm{HCl}$ (pH 8.5) until further use.

PCR annealing temperature optimization was necessary to improve the specificity of algal-virus polymerase amplification. From the sample collected on February 1, 2001, $3 \mu \mathrm{l}$ (ca. $0.5 \%$ of the $40 \mathrm{l}$ sample) of virus-size extract was added to a $47 \mu \mathrm{l}$ PCR mixture containing Taq DNA polymerase assay buffer $(50 \mathrm{mM}$ $\mathrm{KCl}, 20 \mathrm{mM}$ Tris- $\mathrm{HCl}, \mathrm{pH} 8.4$ ), $1.5 \mathrm{mM} \mathrm{MgCl}_{2}, 0.16 \mathrm{mM}$ of each deoxyribonucleoside triphosphate (dNTP), $10 \mathrm{pmol}$ of the primer AVS1 and $30 \mathrm{pmol}$ of AVS2, and 0.625 U of PLATINUM ${ }^{\circledR}$ Taq DNA polymerase (Invitrogen Life Technologies). The degenerate algal-virusspecific primers AVS1 and AVS2 amplify a 700 bp frag- 
ment of pol (Chen \& Suttle 1995). The negative control contained all reagents except template and was placed at the lowest annealing temperature. PCR was carried out in a Hybaid PCR Express thermal cycler with the following cycle parameters: denaturation at $95^{\circ} \mathrm{C}$ for $90 \mathrm{~s} ; 35$ cycles of denaturation at $95^{\circ} \mathrm{C}$ for $45 \mathrm{~s}$; annealing gradient from 42 to $56^{\circ} \mathrm{C}$ for $45 \mathrm{~s}$; and extension at $72^{\circ} \mathrm{C}$ for $45 \mathrm{~s}$ with a final 5 min extension.

Once the PCR annealing temperature was optimized, algal virus pol was amplified using 2 separate PCR reactions. First, $3 \mu \mathrm{l}$ of virus-size extract was added to PCR mixtures as described above. All reaction conditions were as above except the annealing temperature was $45^{\circ} \mathrm{C}$ and only 32 cycles were performed. After electrophoresis, a disposable Pasteur pipette was used to excise a plug from the $700 \mathrm{bp}$ band amplified in each reaction. The plug was placed in $200 \mu$ of sterile $1.0 \times$ TAE ( $40 \mathrm{mM}$ Tris-base, $20 \mathrm{mM}$ sodium acetate, $1 \mathrm{mM}$ EDTA, pH 8.5) and heated to $65^{\circ} \mathrm{C}$ for 20 min to elute DNA. In the second-stage PCR, $2 \mu$ of the eluant was used to increase product yields for the subsequent DGGE analysis. These reactions were identical to firststage PCR except the number of cycles was limited to 20. Second-stage negative controls were conducted using the eluant of plugs excised from the negative control lane of gels of first-stage PCR.

Eukaryotic 18S rDNA fragments were amplified from filter extracts using previously described universal eukaryotic primers Euk1A, Euk516r and Euk516r-GC (Diez et al. 2001). Five $\mu \mathrm{l}$ of a filter extract were added to a $45 \mu \mathrm{l} \mathrm{PCR} \mathrm{mixture} \mathrm{containing} \mathrm{Taq} \mathrm{DNA} \mathrm{polymerase}$ assay buffer $(50 \mathrm{mM} \mathrm{KCl}, 20 \mathrm{mM}$ Tris- $\mathrm{HCl}, \mathrm{pH} 8.4)$, $1.5 \mathrm{mM} \mathrm{MgCl}_{2}, 0.16 \mathrm{mM}$ of each deoxyribonucleoside triphosphate (dNTP), 15 pmol of the $18 \mathrm{~S}$ primers Euk1 A and Euk516r, and 0.625 U of PLATINUM ${ }^{\circledR}$ Taq DNA polymerase. PCR was carried out using a Hybaid PCR Express thermal cycler with the following cycle parameters: denaturation at $95^{\circ} \mathrm{C}$ for $90 \mathrm{~s} ; 32$ cycles of denaturation at $95^{\circ} \mathrm{C}$ for $1 \mathrm{~min}_{\text {; }}$ annealing at $56^{\circ} \mathrm{C}$ for $1 \mathrm{~min}$ and extension at $72^{\circ} \mathrm{C}$ for $1 \mathrm{~min}$ with a final $5 \mathrm{~min}$ extension. Like the algal virus $p o l$ reactions, a second PCR reaction was conducted using first-stage gel plugs as templates. In this case, second-stage reactions were used to incorporate a GC clamp onto the PCR products for the subsequent DGGE analysis. All second-stage PCR conditions were the same as first-stage $18 \mathrm{~S}$ amplification except the downstream primer Euk516r-GC was used and the reaction was limited to 20 cycles.

PCR products were electrophoresed in $1.8 \% \mathrm{LE}$ agarose (FMC BioProducts) in $1.0 \times \mathrm{TAE}$ at $90 \mathrm{~V}$ for $75 \mathrm{~min}$. Gels were stained with ethidium bromide and photographed on an ultraviolet transilluminator with a Nikon Coolpix 950 digital camera. Digital images were inverted and contrast and brightness was adjusted using Adobe Photoshop 5.0 LE.
DGGE and sequencing. Initially, DGGE conditions were optimized for maximum resolution by electrophoresing several samples in different gradient gels. From these gels, bands were excised, eluted and amplified as described above for the templates of second-stage PCR. For each type of DGGE analysis (AVS or 18S), 6 bands were selected and pooled for use as standards in subsequent gradient gels. DGGE of second-stage AVS PCR products was conducted using 20 to $40 \%$ denaturing gradients cast in 7 to $8 \%$ gradient polyacrylamide gels. Approximately $50 \mu \mathrm{l}$ (range 35 to 60 ) of the pooled products of 3 separate second-stage reactions were loaded into wells with $5 \mu$ of $10.0 \times$ loading buffer (50\% v/v glycerol, $0.33 \mathrm{M}$ EDTA, pH 8.0 , and $0.08 \% \mathrm{w} / \mathrm{v}$ bromophenol blue). The amount of pooled PCR products loaded into each lane was normalized after the products were quantified in agarose gels using the program Gel-Pro ${ }^{\circledR}$ Analyzer (Media Cybernetics). Wells flanking the samples were loaded with $45 \mu \mathrm{l}$ of pooled AVS standards. Electrophoresis was carried out for $15 \mathrm{~h}$ in $1.0 \times \mathrm{TAE}$ at $80 \mathrm{~V}$ and a constant temperature of $60^{\circ} \mathrm{C}$ using the D-code ${ }^{\mathrm{TM}}$ electrophoresis system (Bio-Rad Laboratories). Similarly, DGGE of the second-stage 18S PCR products was conducted using 25 to $47.5 \%$ denaturing gradients cast in $6 \%$ polyacrylamide gels. From 40 to $50 \mu \mathrm{l}$ of pooled PCR products of 3 separate second-stage reactions was loaded into each well with $10 \times$ loading buffer; the amount of DNA loaded was normalized as described for AVS-DGGE. Wells flanking the samples were loaded with $40 \mu \mathrm{l}$ of pooled $18 \mathrm{~S}$ standards. Electrophoresis was carried out for $15 \mathrm{~h}$ in $1.0 \times \mathrm{TAE}$ at $100 \mathrm{~V}$ and $59^{\circ} \mathrm{C}$. Gels were stained in a $0.1 \times \mathrm{SYBR}^{\circledR}$ Green I (Molecular Probes) solution overnight, destained in water for at least $30 \mathrm{~min}$ and photographed as described above for agarose gels. Digital images of the denaturing gradient gels were analyzed using the program GelCompar II (Applied-Maths BVBA). For each type of DGGE analysis (AVS or 18S), band positions in individual gel images (6 AVS and 12 18S) were normalized using lanes loaded with the standards. To estimate sample similarities within each fingerprint set (AVS, 18S 0.45 to $1.2 \mu \mathrm{m}$ fraction, and $18 \mathrm{~S}>1.2 \mu \mathrm{m}$ fraction) Pearson product moment correlation coefficients were calculated from lane densitometry plots and were used to calculate UPGMA dendrograms.

Bands from different gel positions were excised from the AVS or $18 \mathrm{~S}$ gradient gels for sequencing. Gel slices were then placed in sterile microcentrifuge tubes with $200 \mu \mathrm{l}$ of $1.0 \times \mathrm{TAE}$, heated to $95^{\circ} \mathrm{C}$ for $5 \mathrm{~min}$ to elute the DNA, and stored at $-20^{\circ} \mathrm{C}$ until further use. Eluted DNA fragments from 10 arbitrarily selected AVS bands were amplified as described above for second-stage AVS reactions. Amplified AVS DNA was then cloned using a pGEM $^{\oplus}$-T Easy kit (Promega). Eluted DNA 
fragments from 19 arbitrarily selected 18S bands were amplified as described for second-stage $18 \mathrm{~S}$ reactions. AVS plasmid DNA (300 to $500 \mathrm{ng}$ ) or $18 \mathrm{~S}$ amplified DNA ( $4 \mu \mathrm{l})$ and an appropriate oligonucleotide primer (M13 forward/reverse or Euk1A/516r, respectively) were added to sequencing reactions using AmpliTaq FS $^{\circledR}$ BIGDYE Terminator cycle sequencing chemistry (Applied Biosystems) and excess dye terminators were removed using CENTRI-SEPTM spin columns (Princeton Separations). Reactions were run in ABI Model 373 Stretch or ABI Prism 377 automated sequencers (Applied Biosystems).

Algal-virus pol sequences obtained from DGGE bands were compared to known virus pol genes available in GenBank (accession numbers listed below). Sequences were edited using BioEdit version 5.0.7 (Hall 1999) and inferred amino acids were aligned using the sequence alignment program CLUSTAL X (Thompson et al. 1997) with default settings. The alignment of the resulting 340 amino acid positions was used to construct a maximum likelihood tree using the program TREE-PUZZLE version 5.0 (Strimmer \& von Haeseler 1996) and phylogenetic trees were drawn using the program TreeView (Win32) version 1.6.1 (Page 1996). The sequences recovered from the $18 \mathrm{~S}$ gels were compared to nucleotide sequences in GenBank (available at www.ncbi.nlm.nih.gov) using blastn and small subunit rDNA sequences in the Ribosomal Database Project II (available at rdp.cme.msu.edu/ html) using Sequence Match (Maidak et al. 2001).

The sequences obtained in this study were deposited in the GenBank database. The accession numbers assigned to the algal-virus sequences JPavs-22, JPavs-37, JPavs-38, JPavs-42, JPavs-51, JPavs-52, JPavs-53, JPavs55, JPavs-64, JPavs-65 were AY145089 to AY145098, respectively. The accession numbers assigned to the $18 \mathrm{~S}$ rDNA sequences JPeuk-1, JPeuk-2, JPeuk-4, JPeuk-6, JPeuk-20, JPeuk-27, JPeuk-38, JPeuk-40, JPeuk-51, JPeuk-59, JPeuk-65, JPeuk-71，JPeuk-77，JPeuk-80, JPeuk-84, JPeuk-94, JPeuk-108, JPeuk-113, JPeuk-119 were AY145099 to AY145117, respectively.

The accession numbers of virus pol sequences used in the phylogenetic analysis are: ASFV, X73330; BSA99-1, AF405577; BSA99-2, AF405578; BSA99-5, AF405581; BSB99-2, AF405588; CbV-PW1，U32983; CbV-PW3, U32984; CVA-1, U32985; EBV, V01555; EsV-1-93, AAK14511; FSV, AAB67116; HSV-1, X04771; HCMV, M14709; MIB99-2, AF405592; MpV-GM1，U32977; MpV-PB8， U32980; MpV-PL1，U32982; MpV-SG1， U32981; MpV-SP1, U32975; NY-2A, M86837; OTU1, U36931; OTU2, U36932; OTU3, U36933; OTU4, U36934; OTU5, U36935; PBCV-1, M86836; PSB99-1, AF405593; PSC99-1, AF405597; PSC99-2, AF405598; SIA99-1, AF405590; SO98-1， AF405572; SO98-2, AF405573; SO98-3, AF405574; SO98-5, AF405576.

\section{RESULTS}

Optimization of algal-virus pol PCR successfully eliminated a previously observed $550 \mathrm{bp}$ artifact (Short \& Suttle 2002). At annealing temperatures above $48^{\circ} \mathrm{C}$, PCR reactions with the February 1, 2001 sample and AVS primers produced 700 and 550 bp bands. The highest yield of the $700 \mathrm{bp}$ band was at the lowest annealing temperature and diminished with increasing temperature, while the highest yield of the $550 \mathrm{bp}$ band was at the highest annealing temperature and disappeared as the temperature decreased to $46^{\circ} \mathrm{C}$ (Fig. 1). Two-stage AVS PCR using $45^{\circ} \mathrm{C}$ annealing temperatures produced only bright 700 bp bands. Similarly, second-stage PCR with $18 \mathrm{~S}$ primers produced only the expected $550 \mathrm{bp}$ DNA fragments (data not shown).

By sequencing and phylogenetic analysis, 10 bands from the AVS fingerprints were characterized. All 10 sequences recovered from the AVS fingerprints encoded the purported pol motif YGDTDS, and comparison to other virus pol sequences revealed that their inferred amino acid sequences fell within the clade of known algal viruses belonging to the Phycodnaviridae (Fig. 2). Although none of the Jericho Pier sequences were identical, the percentage of identical nucleotides was at least 98 among the sequences JPavs-37, JPavs42, JPavs-51 and JPavs-52. Similarly, the sequences JPavs-64 and JPavs-65 were 99.5\%, and JPavs-22 and JPavs-38 were $98.0 \%$ identical. The remaining sequences (JPavs-53 and JPavs-55) were less than $89 \%$ identical to any other sequence. Several sequences were more than $98 \%$ identical to other environmental sequences available in GenBank. For example, the

\section{Temperature}

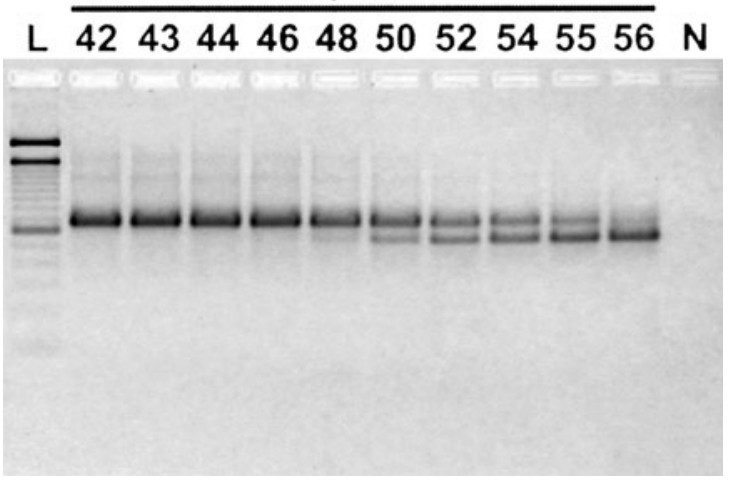

Fig. 1. Annealing temperature gradient of PCR with algalvirus-specific (AVS) primers. Agarose gel loaded with $15 \mu \mathrm{l}$ of PCR products from AVS reactions of the template from February 1, 2001. Numbers indicate the annealing temperature in ${ }^{\circ} \mathrm{C}$. L designates the lane loaded with a $100 \mathrm{bp}$ DNA ladder (Invitrogen) and $\mathrm{N}$ designates the lane loaded with the negative control 
sequences JPavs-64 and JPavs-65 were at least 99\% identical to the sequence BSA99-1, and the sequence JPavs-53 was 99\% identical to SO98-5. Only 1 sequence from the AVS fingerprints (JPavs-55) was less than $90 \%$ identical to any known algal virus pol fragment. Nineteen bands excised from the $18 \mathrm{~S}$ fingerprints were sequenced and compared to sequence databases. When compared to nucleotide sequences in GenBank, all of the sequences recovered from the $18 \mathrm{~S}$ gradient gels were related to $18 \mathrm{~S}$ rDNA sequences. The Jericho Pier $18 \mathrm{~S}$ sequences were related to $18 \mathrm{~S}$ rDNA sequences from several eukaryote

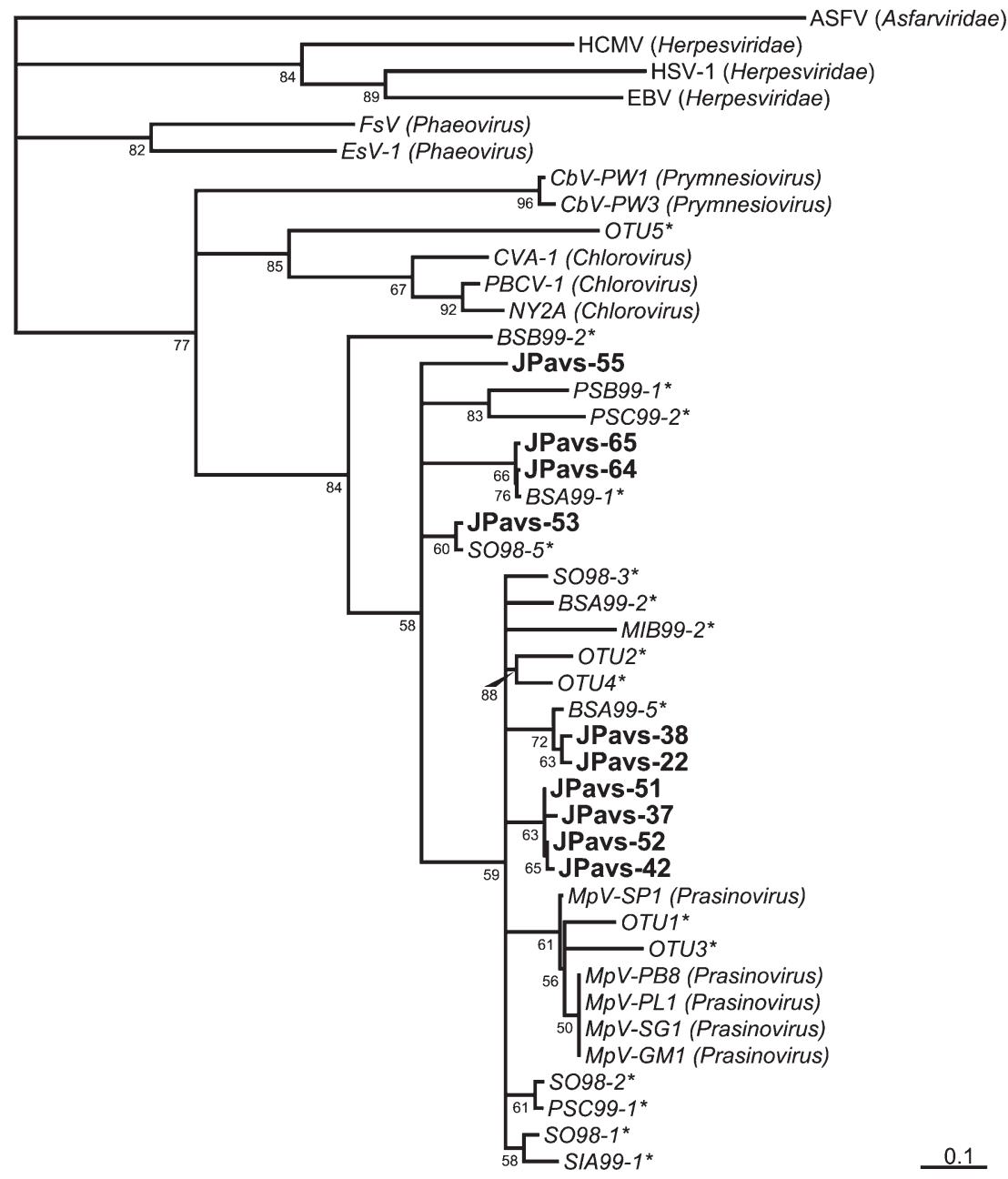

Fig. 2. Maximum likelihood (ML) tree of algal viruses from Jericho Pier. ML tree of inferred amino acid sequences of dsDNA viruses with quartet puzzling support values to the lower left of corresponding nodes. Algal virus pol fragment sequences obtained in this study are shown in bold. All Phycodnaviridae are shown in italics and the genera of cultured viruses are shown in parentheses beside the designation, while uncultivated virus sequences from previous studies are indicated with an asterisk. Virus sequences from the classes Herpesviridae and Asfarviridae are included as references and as an outgroup. The GenBank accession numbers of all sequences are provided in 'Materials and methods'.

Scale bar indicates the number of amino acid substitutions per position lineages including Alveolata, Fungi, Metazoa, Stramenopiles and Viridiplantae (Table 1).

The salinity and temperature of the water at Jericho other times of the year. With the exception of the winter months, when it was lowest, chl a concentrations were variable. Because the local tidal cycle is mixed diurnal, the tide height at Jericho Pier varied considerably among the times of sample collection.

Visual inspection of the composite DGGE images revealed that the banding patterns of the AVS fingerprints (Fig. 3) appeared less variable than the 18S fingerprints (Fig. 4). Throughout most of the study period, especially during the spring, the $18 \mathrm{~S}$ fingerprint patterns changed from week to week while the AVS patterns were relatively constant. Nonetheless, bands present throughout most of the sample period were observed in all 3 fingerprints. The bands indicated at Position 1 in the AVS fingerprint can be observed in all but a few samples (Fig. 3), and Bands euk51 and euk113 were present in the majority of the $18 \mathrm{~S}$ samples from the 0.45 to 1.2 and $>1.2 \mu \mathrm{m}$ fractions respectively (Fig. 4). On the other hand, some bands were observed in only a few samples. Band avs55 was observed only during the winter and early spring of each year; this band was present from the beginning of the study until April 7, 2000 and reappeared from January 25, 2001 until April 4, 2001. In addition, Band avs53 was present only in February and March 2001, and Bands 1 and 2 in the 0.45 to 1.2 and $>1.2 \mu \mathrm{m} 18 \mathrm{~S}$ fractions (Fig. 4) appeared only once. Overall, patterns of band appearance and disappearance were observed in all fingerprints.

Visual inspection also revealed changing fingerprint patterns coincident with changes in the physical characteristics of samples from Jericho Pier. From November 2000 through February 2001, the salinity was $>25$ ppt, the temperature was $<15^{\circ} \mathrm{C}$ and chl a concentrations were $<3 \mu g \mathrm{l}^{-1}$. During these months, the $18 \mathrm{~S}$ fingerprints of 
Table 1. Results of 18S ribosomal database searches with Jericho Pier sequences

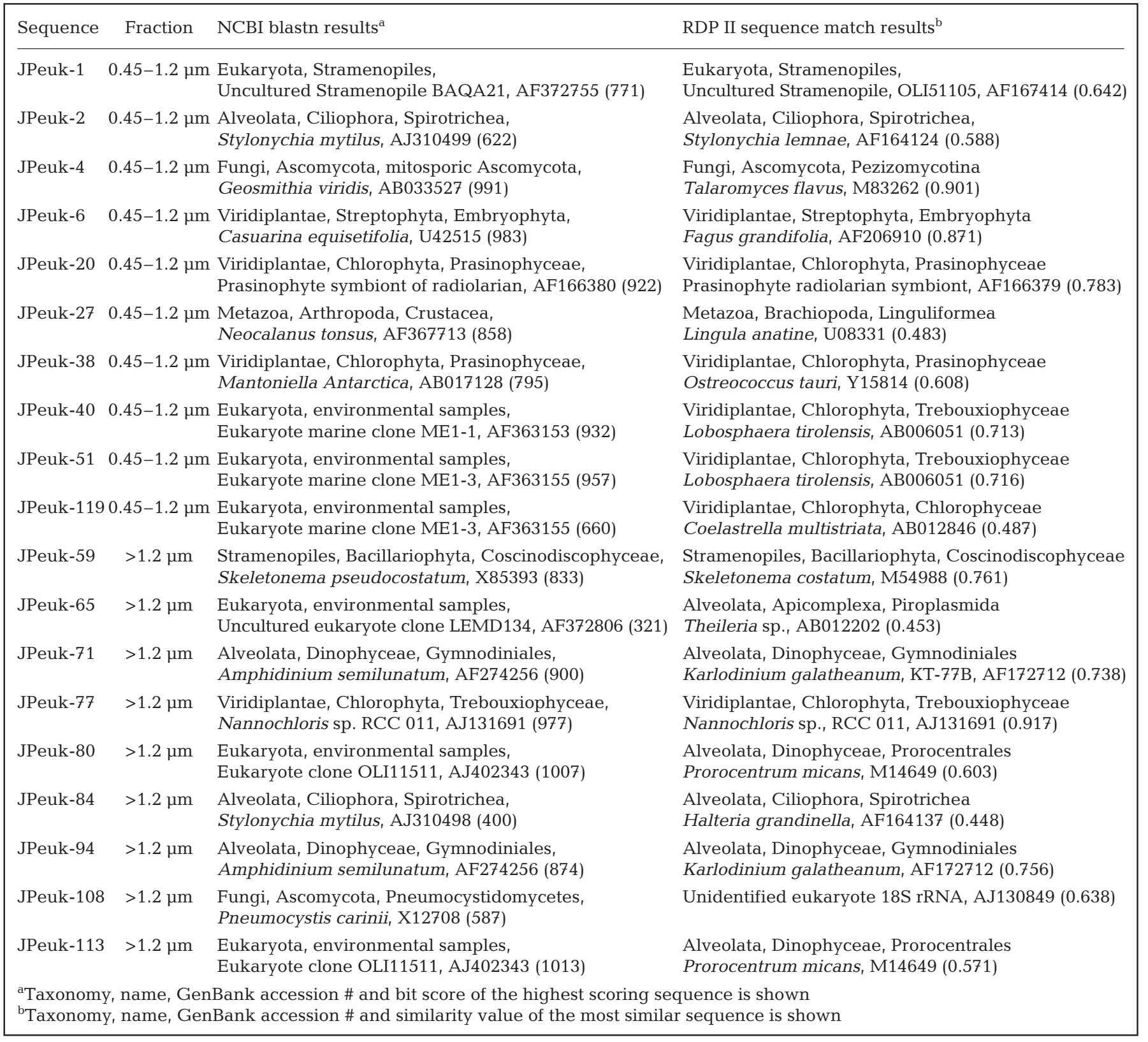

both fractions appeared less variable than at other times of the year (Fig. 4). Similarly, the AVS fingerprints remained relatively constant through the winter months, albeit with later timing than the $18 \mathrm{~S}$ fingerprints; the AVS fingerprints changed little from the middle of December to the middle of March (Fig. 3). Within the study period, the chl a concentration was highest on July 27, 2000 at approximately $59 \mathrm{\mu g} \mathrm{l}^{-1}$. High concentrations were also observed on October 5,

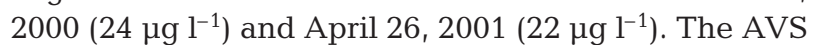
fingerprint pattern on October 5, 2001 (Lane B, Fig. 3) changed relative to the flanking fingerprints, while the fingerprints from the July 27, 2000 and April 26, 2001 did not appear significantly different from their flanking fingerprints (Lanes A and C, respectively, Fig. 3).

Cluster analysis of each fingerprint set and inspection of the resulting UPGMA trees revealed that the AVS fingerprints were more similar to one another than were the $18 \mathrm{~S}$ fingerprints (Fig. 5). With the exception of the samples collected on March 10 and May 19, 2000, samples from March to May 2000 (white bars, Fig. 5) clustered beside one another in the AVS tree, yet were distributed among 5 separate clusters in each $18 \mathrm{~S}$ dendrogram. Similarly, the fingerprints from mid- 


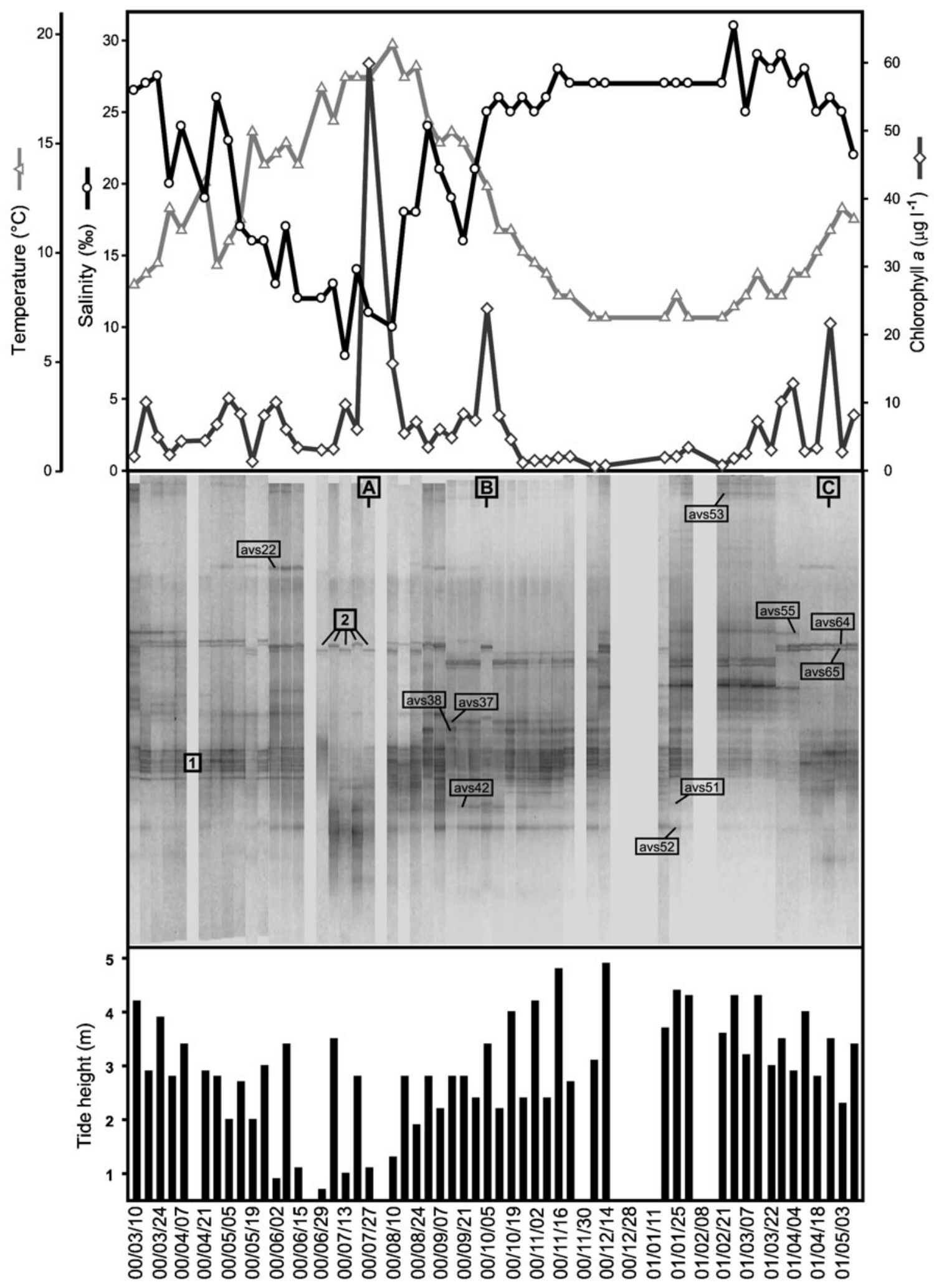

Fig. 3. Physical data and algal-virus-specific (AVS) fingerprints from Jericho Pier. Top: salinity, temperature and chlorophyll $a$ in weekly samples collected at Jericho Pier. Middle: composite image of AVS fingerprints. Annotations on the gel image show the positions of bands sequenced and lanes or bands discussed in the text. Bottom: predicted tidal heights at the time of sample collection are shown in the bottom panel. Sample dates are written as yy/mm/dd 


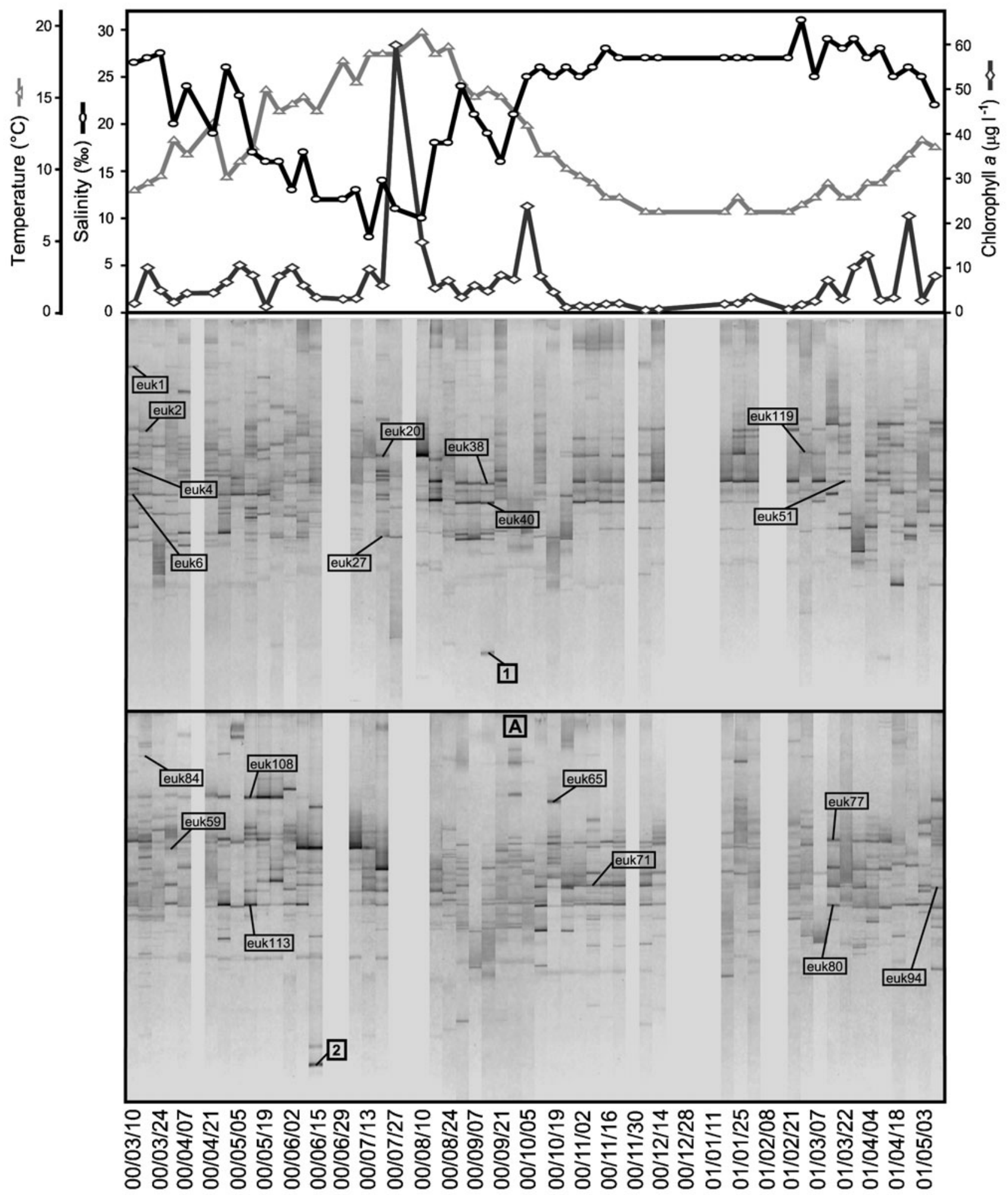

Fig. 4. Physical data and 18S rDNA fingerprints from Jericho Pier. Top: salinity, temperature and chlorophyll $a$ in weekly samples collected at Jericho Pier. Middle: DGGE fingerprints of 18S rDNA amplified from 0.45 to $1.2 \mu$ m size fraction extracts. Bottom: DGGE fingerprints of $18 \mathrm{~S}$ fingerprints from the $>1.2 \mu \mathrm{m}$ size fraction extracts. Annotations show the positions of bands sequenced and lanes or bands discussed in the text. Sample dates are written as yy/mm/dd 


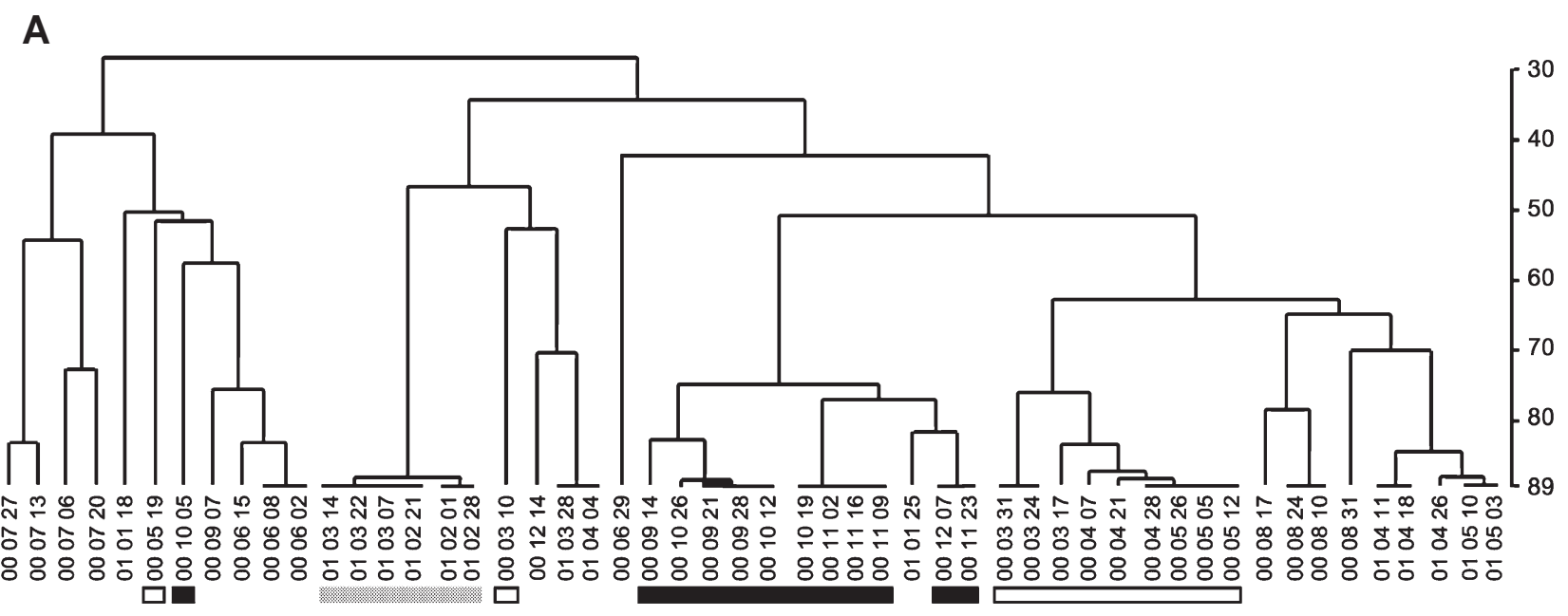

B

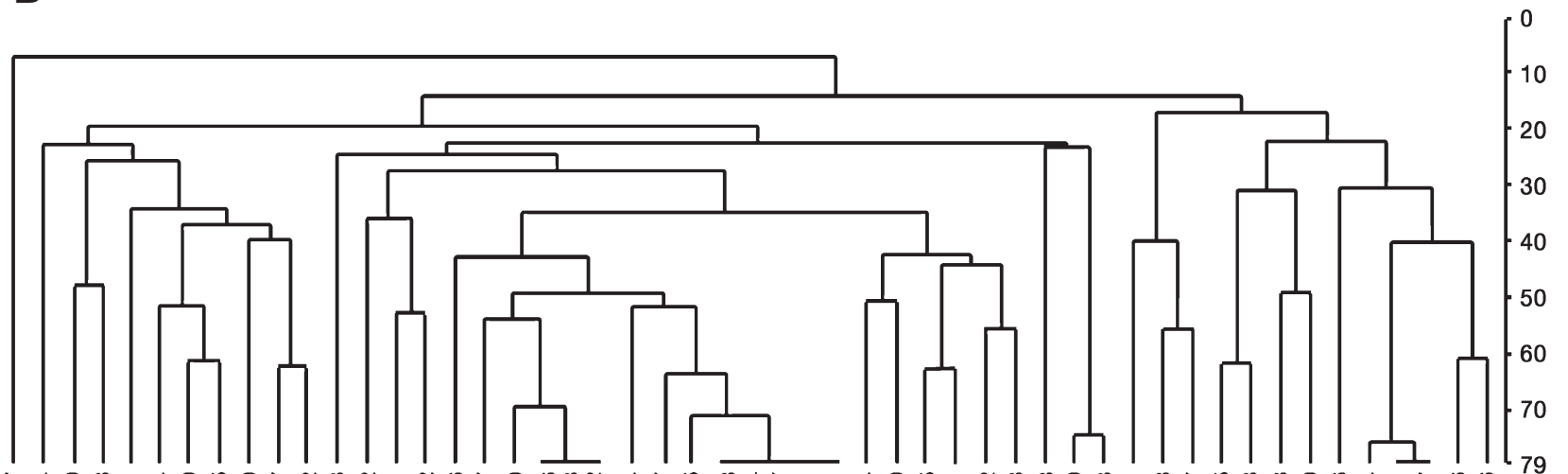
N

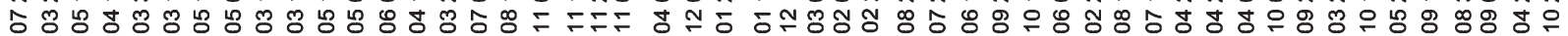
৪৪

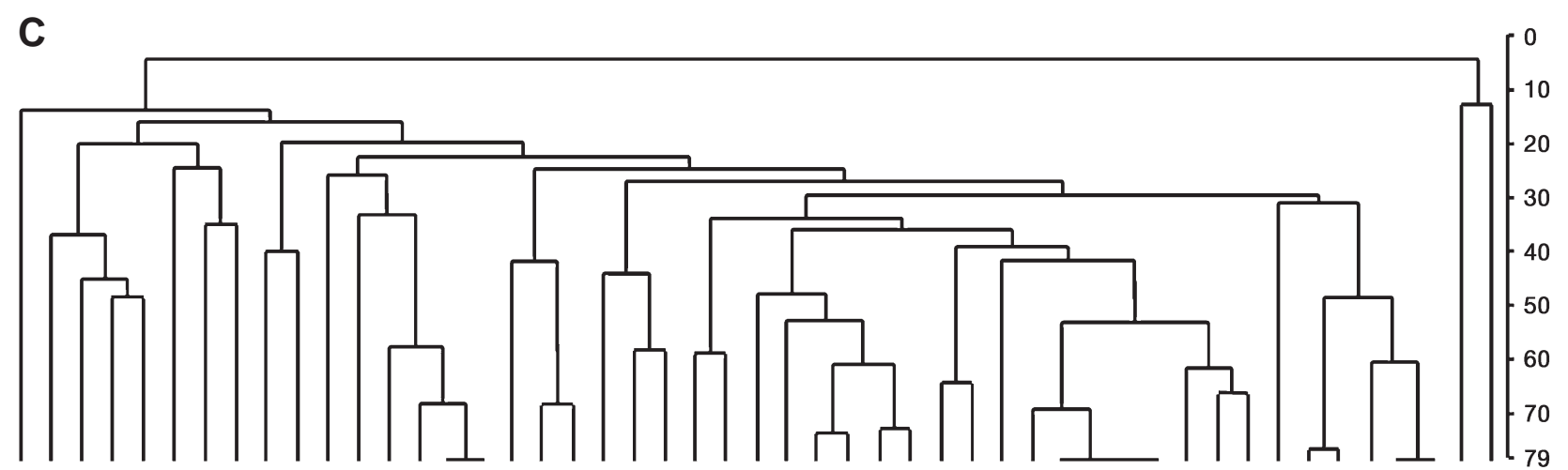

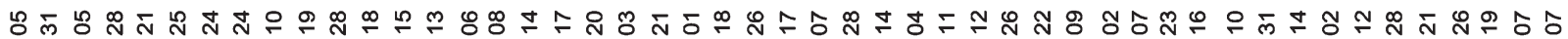

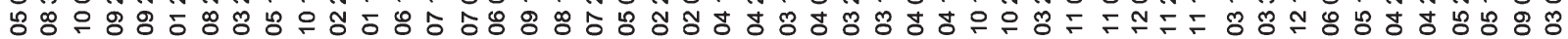

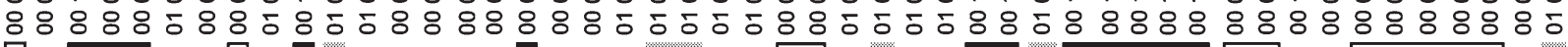

Fig. 5. DGGE fingerprint cluster analysis. UPGMA trees of sample similarities for (A) the algal-virus-specific (AVS), (B) 0.45 to $1.2 \mu \mathrm{m} \mathrm{18S}$ and $(\mathrm{C})>1.2 \mu \mathrm{m} \mathrm{18S}$ fingerprints. The scales to the right of each dendrogram show percent similarity. The resolution of each tree (maximum similarity) was estimated from the minimum similarity of standard lanes (data not shown). The black, grey and white bars below the dates of each dendrogram show the positions of sequences discussed in the text. Sample dates are written as $y y / m m / d d$ 
September to early December (black bars, Fig. 5) and from February through March 2001 (grey bars, Fig. 5) formed a fewer clusters in the AVS dendrogram compared to 18S. In general, UPGMA analysis of pairwise densitometry correlations illustrated that AVS fingerprints were more similar to one another and samples from the same time of year tended to form fewer and more similar clusters when compared to $18 \mathrm{~S}$ fingerprints.

\section{DISCUSSION}

The goal of this study was to observe changes in algal virus communities at Jericho Pier over several months and relate them to eukaryote diversity, chl a concentration, temperature, salinity and tidal height. Sequencing efforts revealed at least 5 distinct groups of viruses and several kingdoms of eukaryotes. We discovered that, at certain times, tide height and salinity changes were coincident with changes in the algal virus community composition. On 1 occasion, a phytoplankton bloom was also coincident with a shift in the algal virus community structure. In general, the composition of the detected algal virus communities was temporally less variable than that of the eukaryote communities.

Before algal virus communities could be monitored using molecular techniques, the fidelity of PCR with the primers AVS1 and AVS2 had to be improved. Established PCR conditions permitted amplification of sequences not related to algal virus pol fragments. Previously, we demonstrated that production of these PCR artifacts was due to amplification from the upstream primer AVS1 alone (Short \& Suttle 2002). Because the melting temperature of AVS1 is ca. $10^{\circ} \mathrm{C}$ higher than AVS2, efforts to increase reaction specificity by increasing annealing temperature failed. Therefore, it is likely that increased reaction specificity at lower annealing temperatures was due to an increase in AVS2 annealing efficiency. It is notable that every band sequenced in this study fell within a monophyletic group of known algal virus pol sequences (Fig. 2), providing strong evidence that the fingerprints represented algal virus pol fragments only.

Many algal virus sequences recovered from Jericho Pier were more than $98 \%$ identical to each other and to sequences from other environmental samples. Two sets of sequences (JPavs64 \& 65 and JPavs51 \& 52) differed by only 2 and $3 \mathrm{nt}$, respectively. These sequences were recovered from bands at different positions in the fingerprint, and differences were due to nucleotides incorporated at sites of primer degeneracy. Therefore, quantitative examination of algal virus richness was not possible with degenerate primer PCR and DGGE.
Nonetheless, when primer sequences were excluded, no algal virus sequences were more than $99.8 \%$ identical, and it is unlikely that observed differences were due to PCR error alone. Using reported Taq error rates (Bracho et al. 1998), 1 misincorporated base per sequence can be estimated during algal virus pol amplification resulting in an identity difference of only $0.1 \%$. Currently, we do not know if pol sequences differing by less than $1 \%$ represent different strains or ecotypes of viruses. Nonetheless, the 10 sequences recovered from Jericho Pier resolved onto 5 separate branches of the maximum likelihood tree (Fig. 2), and the minimum difference between any 2 of these branches was ca. $8 \%$. Therefore, it is likely that each of the 5 branches represent distinct taxa of uncultivated viruses. All sequences recovered from the $18 \mathrm{~S}$ fingerprints were related to small subunit rDNA sequences. While the majority of sequences recovered from the 18S fingerprints were related to phytoplankton, 3 sequences were related to zooplankton, 2 to fungi and 1 to a terrestrial plant. However, because only a limited number of bands were sequenced, the recovered sequences did not quantitatively represent the organisms present. Nonetheless, sequences from the $18 \mathrm{~S}$ fingerprints demonstrated that several kingdoms of eukaryotes were detected with the described PCR methods.

During this study, changes in the virus fingerprints were often related to the physical characteristics of the water at Jericho Pier. The relationship between algal virus community dynamics and the physical environment was apparent when AVS fingerprints were compared to tide height. At certain times, changes in the tide height coincided with changes in the AVS fingerprint patterns. The bands indicated at Position 2 in the AVS fingerprints of samples collected from June 29 to August 10, 2000, alternated position coincident with changes in tide height (Fig. 3). However, at other times, fingerprint changes were not coincident with tide height changes. Intra-annual variability of the tidal influence on virus communities may be related to other aspects of the physical characteristics of the sample site. During the weeks that tide height changes were coincident with changes in the pattern of successive AVS fingerprints, the salinity was lowest indicating that the Fraser River freshet had peaked; the surface water at Jericho Pier is strongly influenced by freshwater input from the Fraser River (Harrison et al. 1983). During the freshet, freshwater surface flow may have caused more pronounced shifts in phytoplankton and virus community composition as the water at Jericho Pier ebbed and flooded.

Another example of an environmental influence on AVS fingerprint patterns was the change in the pattern coincident with 1 of the 3 phytoplankton blooms 
observed during the study; during each bloom chl a concentrations exceeded $20 \mu \mathrm{g} \mathrm{l}^{-1}$. These blooms occurred in summer 2000, autumn 2000 and early spring 2001 (Lanes A, B and C, Fig. 3). Examination of Lugol's iodine-preserved samples (Parsons et al. 1984) revealed that the summer bloom was a nearly monospecific bloom of the Raphidophyte Heterosigma akashiwo. In contrast, the fall bloom was mixed and dominated by the diatoms Ditylum, Leptocylindrus and Pseudonitzschia, and the dinoflagellates Prorocentrum, Dinophysis and Protoperidinium; the 2001 spring bloom was dominated by the diatoms Skeletonema, Chaetoceros and Thalassiosira. The fact that the AVS fingerprint did not change during the summer Heterosigma bloom or the spring diatom bloom was explicable. Although isolates of viruses that infect Heterosigma are established in culture (Nagasaki \& Yamaguchi 1997, Lawrence et al. 2001), we have not successfully amplified pol sequences from these viruses, suggesting that the AVS primers are not suitable. Also, to our knowledge, no viruses that infect diatoms have been isolated. During the mixed diatom and dinoflagellate bloom of the fall, the $>1.2 \mu \mathrm{m}$ fraction 18S fingerprint contained many bands, suggesting that the bloom was of a diverse group of phytoplankton (Lane A, Fig. 4). At the same time, the band pattern of the AVS fingerprints changed relative to the fingerprints from surrounding weeks. While this does not establish a causal relationship between changes in eukaryote richness and AVS fingerprints, the coincidence is intriguing; the presence of Phycodnaviridae hosts is most probable when eukaryote diversity was high. Because not all phytoplankton blooms were coincident with AVS fingerprint changes, it is likely that the viruses detected with the AVS primers do not infect the dominant bloom-forming algae at Jericho Pier.

In general, algal virus fingerprints were less variable than eukaryote fingerprints. This contrasting variability of the 2 communities was not surprising; the viruses detected with the AVS primers all belonged to the Phycodnaviridae (dsDNA viruses that infect eukaryotic phytoplankton), and therefore infected only a small subset of eukaryotes. Although the majority of sequences from the $18 \mathrm{~S}$ fingerprints were related to phytoplankton, several were not. Because only a limited number of bands were sequenced from the $18 \mathrm{~S}$ fingerprints, the ratios of taxa represented in the sequence data were not used to estimate the abundance of different eukaryote groups. Nonetheless, 18S sequences revealed the presence of many organisms that were not hosts of phycodnaviruses. The presence of non-host organisms may explain the lack of correspondence between virus and eukaryote community dynamics. We can speculate that changes in algal virus communities were coupled to changes in host commu- nities. On the other hand, it is likely that changes in the $18 \mathrm{~S}$ fingerprints due to the succession of non-host eukaryotes were not coupled to changes in the AVS fingerprints. In the future, development of PCR methods to fingerprint specific groups of phytoplankton, when combined with the virus fingerprinting methods outlined here, will permit direct comparison of changes in algal virus communities and their hosts.

To minimize the possibility that seasonal patterns were due to within-gel biases (as noted by Ferrari \& Hollibaugh 1999), the order of samples loaded in the gradient gels was arbitrary. Despite limitations of fingerprint cluster analysis, gel comparison software was essential to this study; the normalization of individual samples and alignment of common bands within a fingerprint set was not possible without it. Computerized normalization and alignment permitted temporal ordering of fingerprints not run in successive gel lanes. The fingerprint approach described provided useful qualitative information on the temporal variability of algal viruses and eukaryotes; in all 3 fingerprint sets, bands appeared and disappeared in successive samples and, within each set, patterns and variability changed with time. In addition, the lack of coincidence between changes in algal virus and eukaryote community composition was demonstrated by cluster analysis of the fingerprints. The minimum similarity of any branches on AVS tree was higher than the minimum on the $18 \mathrm{~S}$ trees and, when compared to $18 \mathrm{~S}$ fingerprints, the AVS fingerprints clustered into groups with higher minimum similarity (Fig. 5). The cluster analyses also showed that the AVS fingerprints from the same season tended to cluster in larger groups than the 18S fingerprints.

There is accumulating evidence that some phytoplankton are infected by viruses not closely related to the Phycodnaviridae (Lawrence et al. 2001, Tai et al. 2002). In addition, our attempts to amplify pol genes from several viruses that are morphologically similar to the Phycodnaviridae have always failed. Thus, it is apparent that the viruses detected with the AVS primers used in this study likely represent a subset of the Phycodnaviridae. Therefore, the lack of coincidence between changes in algal virus and eukaryote communities at Jericho Pier was not surprising. Although they were not always coupled, changes in algal virus and eukaryote community composition were observed throughout the sample period, suggesting seasonality and succession in both communities. Nonetheless, through most of this study, eukaryote community composition was highly variable, yet algal virus community composition was relatively stable. This is the first study demonstrating that specific taxa of algal viruses are temporally stable and can persist in fluctuating physical and biological environments. This sug- 
gests that the production of some taxa of algal-viruses is constant, and therefore they are a constant source of mortality to some phytoplankton. Hence, we speculate that these viruses influence phytoplankton community structure and may help maintain high host diversity.

Acknowledgements. We would like to acknowledge A. I. Culley, C. M. Frederickson and N. Taylor for their help with sample collection and filtration. We also wish to thank W. W. Mohn for his assistance with computerized gel analysis. This research was supported in part by Natural Sciences and Engineering Research Council (NSERC) research grants to C.A.S. and an NSERC post-graduate scholarship to S.M.S.

\section{LITERATURE CITED}

Bracho MA, Moya A, Barrio E (1998) Contribution of Taq polymerase-induced errors to the estimation of RNA virus diversity. J Gen Virol 79:2921-2928

Bratbak G, Egge JK, Heldal M (1993) Viral mortality of the marine alga Emiliania-Huxleyi (Haptophyceae) and termination of algal blooms. Mar Ecol Prog Ser 93:39-48

Bratbak G, Thingstad F, Heldal M (1994) Viruses and the microbial loop. Microb Ecol 28:209-221

Casamayor EO, Massana R, Benlloch S, Ovreas L and 6 others (2002) Changes in archaeal, bacterial and eukaryal assemblages along a salinity gradient by comparison of genetic fingerprinting methods in a multipond solar saltern. Environ Microbiol 4:338-348

Castberg T, Larsen A, Sandaa RA, Brussaard CPD and 5 others (2001) Microbial population dynamics and diversity during a bloom of the marine coccolithophorid Emiliania huxleyi (Haptophyta). Mar Ecol Prog Ser 221:39-46

Chen F, Suttle CA (1995) Nested PCR with 3 highly degenerate primers for amplification and identification of DNA from related organisms. Biotechniques 18:609-612

Chen F, Suttle CA (1996) Evolutionary relationships among large double-stranded DNA viruses that infect microalgae and other organisms as inferred from DNA polymerase genes. Virology 219:170-178

Chen F, Suttle CA, Short SM (1996) Genetic diversity in marine algal virus communities as revealed by sequence analysis of DNA polymerase genes. Appl Environ Microbiol 62:2869-2874

Diez B, Pedros-Alio C, Marsh TL, Massana R (2001) Application of denaturing gradient gel electrophoresis (DGGE) to study the diversity of marine picoeukaryotic assemblages and comparison of DGGE with other molecular techniques. Appl Environ Microbiol 67:2942-2951

Ferrari VC, Hollibaugh JT (1999) Distribution of microbial assemblages in the Central Arctic Ocean Basin studied by PCR/DGGE: analysis of a large data set. Hydrobiologia 401:55-68

Ferris MJ, Nold SC, Revsbech NP, Ward DM (1997) Population structure and physiological changes within a hot spring microbial mat community following disturbance. Appl Environ Microbiol 63:1367-1374

Fuhrman JA (1999) Marine viruses and their biogeochemical and ecological effects. Nature 399:541-548

Hall TA (1999) BioEdit: a user-friendly biological sequence alignment editor and analysis program for Windows 95/98/NT. Nucl Acids Symp Ser 41:95-98

Harrison PJ, Fulton JD, Taylor FJR, Parsons TR (1983) Review of the biological oceanography of the Strait of
Georgia: pelagic environment. Can J Fish Aquat Sci 43: 1064-1094

Lawrence JE, Chan AM, Suttle CA (2001) A novel virus (HaNIV) causes lysis of the toxic bloom-forming alga Heterosigma Akashiwo (Raphidophyceae). J Phycol 37: $216-222$

Maidak BL, Cole JR, Lilburn TG, Parker CTJ and 5 others (2001) The RDP-II (Ribosomal Database Project). Nucleic Acids Res 29:173-174

Murray AE, Hollibaugh JT, Orrego C (1996) Phylogenetic compositions of bacterioplankton from two California estuaries compared by denaturing gradient gel electrophoresis of 16s rDNA fragments. Appl Environ Microbiol 62:2676-2680

Muyzer G, De Waal EC, Uitterlinden AG (1993) Profiling of complex microbial populations by denaturing gradient gel-electrophoresis analysis of polymerase chain reaction amplified genes coding for 16S ribosomal RNA. Appl Environ Microbiol 59:695-700

Nagasaki K, Yamaguchi M (1997) Isolation of a virus infectious to the harmful bloom causing microalga Heterosigma akashiwo (Raphidophyceae). Aquat Microb Ecol 13: $135-140$

Ogino A, Koshikawa H, Nakahara T, Uchiyama H (2001) Succession of microbial communities during a biostimulation process as evaluated by DGGE and clone library analyses. J Appl Microbiol 91:625-635

Page RDM (1996) TREEVIEW: an application to display phylogenetic trees on personal computers. Comput Appl Biosci 12:357-358

Parsons TR, Maita Y, Lalli CM (1984) A manual of chemical and biological methods for seawater analysis. Pergamon Press, New York

Sambrook J, Fritsch EF, Maniatis T (1989) Molecular cloning: a laboratory manual. Cold Spring Harbor Laboratory Press, Cold Spring Harbor, NY

Short SM, Suttle CA (1999) Use of the polymerase chain reaction and denaturing gradient gel electrophoresis to study diversity in natural virus communities. Hydrobiologia 401: $19-32$

Short SM, Suttle CA (2000) Denaturing gradient gel electrophoresis resolves virus sequences amplified with degenerate primers. Biotechniques 28:20-26

Short SM, Suttle CA (2002) Sequence analysis of marine virus communities reveals that groups of related algal viruses are widely distributed in nature. Appl Environ Microbiol 68:1290-1296

Steward GF, Montiel JL, Azam F (2000) Genome size distributions indicate variability and similarities among marine viral assemblages from diverse environments. Limnol Oceanogr 45:1697-1706

Strimmer K, von Haeseler A (1996) Quartet puzzling: a quartet maximum-likelihood method for reconstructing tree topologies. Mol Biol Evol 13:964-969

Suttle CA (1994) The significance of viruses to mortality in aquatic microbial communities. Microb Ecol 28:237-243

Suttle CA (2000) The ecological, evolutionary and geochemical consequences of viral infection of cyanobacteria and eukaryotic algae. In: Hurst CJ (ed) Viral ecology. Academic Press, San Diego, p 247-296

Suttle CA, Chan AM, Cottrell MT (1991) Use of ultrafiltration to isolate viruses from seawater which are pathogens of marine-phytoplankton. Appl Environ Microbiol 57: 721-726

Tai V, Lawrence JE, Lang AS, Culley AE, Chan AM, Suttle CA (2003) Characterization of HaRNAV, a single-stranded RNA virus causing lysis of Heterosigma akashiwo (Raphi- 
dophyceae). J Phycol 39:343-352

Thingstad TF, Heldal M, Bratbak G, Dundas I (1993) Are viruses important partners in pelagic food webs? Trends Ecol Evol 8:209-213

Thompson JD, Gibson TJ, Plewniak F, Jeanmougin F, Higgins DG (1997) The ClustalX windows interface: flexible strategies for multiple sequence alignment aided by quality analysis tools. Nucleic Acids Res 24:4876-4882

Van Hannen EJ, Van Agterveld MP, Gons HJ, Laanbroek HJ (1998) Revealing genetic diversity of eukaryotic microorganisms in aquatic environments by denaturing gradient gel electrophoresis. J Phycol 34:206-213

Editorial responsibility: Gunnar Bratbak, Bergen, Norway
Wilhelm SW, Suttle CA (1999) Viruses and nutrient cycles in the sea. BioScience 49:781-788

Wilson WH, Fuller NJ, Joint IR, Mann NH (2000) Analysis of cyanophage diversity in the marine environment using denaturing gradient gel electrophoresis. In: Bell CR, Brylinsky M, Johnson-Green P (eds) Proc 8th Int Symp Microb Ecol. Atlantic Canada Society for Microbial Ecology, Halifax

Wommack KE, Ravel J, Hill RT, Chun JS, Colwell RR (1999) Population dynamics of Chesapeake Bay virioplankton: total community analysis by pulsed-field gel electrophoresis. Appl Environ Microbiol 65:231-240

Submitted: December 19, 2002; Accepted: March 7, 2003 Proofs received from author(s): May 28, 2003 